\title{
https://doi.org/10.46813/2021-134-080 \\ MILLIMETER-WAVELENGTH RELATIVISTIC MAGNETRON: PROBLEMS OF MICROWAVE POWER EXTRACTION
}

\author{
N.P. Gadetski, V.G. Korenev, A.N. Lebedenko, I.I. Magda, O.G. Melezhik, V.G. Sinitsin, \\ A.A. Shtanko, N.V. Volovenko \\ National Science Center "Kharkov Institute of Physics and Technology”, Kharkiv, Ukraine \\ E-mail:magda@kipt.kharkov.ua
}

The relativistic magnetrons operating at millimeter wavelengths demonstrate problems with microwave power extraction, both in the radial and in axial direction. The preferred axial extraction concept can be implemented either as 'diffractional output' or via introduction of additional resonant elements into the output waveguide. In this paper several solutions for axial-directed extraction are discussed, including circular ring 'antennas' at the end of the anode-cathode space, and resonance-length rods at the faces of the anode-block cavities. These have allowed increasing the power extraction efficiency by a factor of $10^{1}$ to $10^{2}$.

PACS: 52.75.Pv; 52.80.Pi

\section{INTRODUCTION}

As has been noted earlier [1], the millimeterwavelength relativistic magnetron $(\mathrm{RM})$ is characterized by several conceptual distinctions from the devices operating at decimeter or even centimeter wavelengths, e.g. [2]. First, a limit exists on the outer diameter of the magnetron's electrodynamic structure (EDS). It shall not be less than $20 \mathrm{~mm}$ (which is well in excess of the generated line's wavelength) because of precautions against electric breakdowns associated with pulsed voltages of a few hundred kilovolt which are applied to the cathode unit. Another reason for increasing the size of the cathode-anode gap is the expected operation with anode current cut-offs. Next, the number of 'resonant' cavities at the periphery of the circular slow-wave structure may be as large as several tens to avoid overvoltages between side walls, accordingly the cavities are, more often than not, too small to accommodate inside an electrode for output. The high pulsed power generated (a few megawatts and more) suggests the use of an output waveguide of a large cross-section (oversized guide), thus imply-ing axial mode of microwave extraction. Structures of the kind were suggested and investigated for the centimeter waveband back in the 1990s at the Institute for Problems of Physics, Russian Academy of Sciences [4], and later in the USA [5]. The devices were given the name of relativistic magnetrons with axial output of microwaves (RMAO).

Millimeter waveband RMAOs were first created in 2008 at the National Science Center 'Kharkiv Institute of Physics and Technology'(NSC KIPT) [1]. The high voltage pulsed power supply for that magnetron (voltage levels of 200 to $450 \mathrm{kV}$; $45 \mathrm{~ns}$ pulse width) was built around the earlier available dual forming line with a $16 \mathrm{Ohm}$ output impedance. That impedance was too low compared with the impedance of the magnetized coaxial diode repre-senting the millimeter-waveband RMAO (specifi-cally, close to $100 \mathrm{Ohm}$ ). The results were multiple pulse reflections in the power supply system of the RMAO, and a noticeably increased pulse duration. The characteristic width of the anode-cathode gap in a millimeter-waveband magnetron never exceeding a few millimeters, the high voltages across the gap could produce noticeable plasma flows in the anode- cathode space. These provoked instability in magnetron operation and quick erosion of the slow-wave structure (SWS) [6].

In 2017, a new high-voltage, pulsed power supply was created for the magnetron (voltage range 200 to $400 \mathrm{kV}$; pulse duration $20 \mathrm{~ns}$, and output impedance $80 \Omega$ ). That permitted an essentially matched regime for the magnetron with respect to the power supply and, accordingly, a greatly increased term of service for the SWS which now could withstand 2.000 or 3.000 pulse shots. That insured stable operation of the magnetron and repeatability of experimental results [7]. Consequently, our team was able to perform a detailed analysis of the axial mode of microwave power extraction. The results of numerical modeling and experimental studies are given below.

\section{SELECTING RMAO PARAMETERS}

At an early stage of work, the SWS was placed inside an 'oversized' (diameter $d_{\mathrm{wg}}=80 \mathrm{~mm}$ ) output waveguide. The anode and the cathode diameters were, accordingly, $d_{\mathrm{A}}=22 \mathrm{~mm}$ and $d_{\mathrm{C}}=12 \ldots 16 \mathrm{~mm}$, with the cathode-anode gap $d_{\mathrm{CA}}=3 \ldots 5 \mathrm{~mm}$. The end part of the entire electrodynamic structure (EDS) accommodated a matching horn. The general view of the EDS with the horn, intended for extracting the microwave power along the waveguide's axis, and sizes of all the components are given in Fig. 1. Versions of the EDS with 30. 40 and 48 cavities were investigated, and the most complete results obtained for the 48-cavity structure [6]. Experiments with the RM-48 magnetron revealed microwave generation at 36 to $41 \mathrm{GHz}$ with magnetic induction $B_{0}=0.35 \ldots 0.8 \mathrm{~T}$ and anode voltages $U_{0}=190$ to $250 \mathrm{kV}$. The oscil-lations excited could be identified as belonging to the $\pi / 2 ; \pi$, or $(2 / 3) \pi$ modes within the principal and first higher-order pass bands. These operation regimes of the magnetron seemed to be in agreement with Hull's cut-off condition, as well as with that of resonant excitation of its EDS by a Brillouin electron flow drifting in crossed $\boldsymbol{E}$ - and $\boldsymbol{H}$-fields. Yet, the net outcome of the experiments with a horn-supported axial extraction of microwave power shall be characterized as unsatisfactory. Indeed, the RF power at the RMAO output never exceeded $100 \mathrm{~kW}$, while the e-beam power at 
the entrance to the EDS was about $400 \mathrm{MW}$, meaning an efficiency below 0.1 per cent. That was in a drastic contrast with the results of experimentation with centimeter wavelength RMAOs which demonstrated efficiencies about 10 per cent [5].

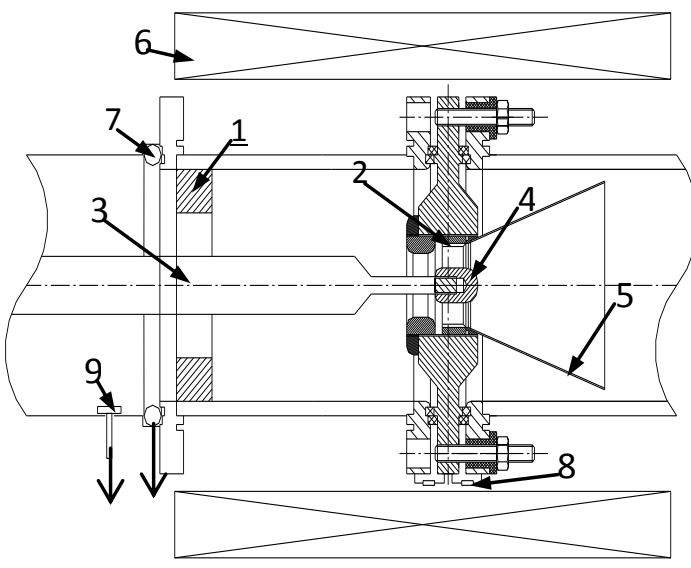

Fig. 1. Schematic of the $8 \mathrm{~mm}$ RM. 1 -Return current collector; 2 -Anode; 3 -Cathode holder; 4 -Cathode;

5 -Output horn; 6 -Solenoid; 7 -Rogowski coil; 8 -Shunts of anode and collector currents; 9 - Capacitive divider

In order to find out the reasons for as low magnetron efficiency, measurements of the anode current of the RMAO were carried out, using a set of current sensors placed around the EDS [8]. The measurements showed an anode current in the course of generation that reached magnitudes of hundreds of amperes. That witnessed a fairly high microwave power (up to several tens of MW) excited in the EDS under typical operation regimes, but at the same time an extremely low efficiency of the axial extraction.

The problem required some kind of a physical insight and especially, a 3D numerical simulation of the relativistic magnetron. Note that the electron beam drifting through the anode-cathode space under the action of crossed d.c. $\boldsymbol{E}$ and $\boldsymbol{H}$ fields can interact effectively only with hf fields of the TE set of modes (via coupling to the field component $E_{\varphi}$ ). Accordingly, the natural path for extracting the microwaves seems to be through the SWS cavities, i.e. in the radial direction. As has been just discussed, this is good for decimeter wavelengths but technically inconvenient in the millimeter wave- band. In order to organize an efficient extraction of microwaves along the magnetron's axis of symmetry $z$, non-zero field components from the TM set $\left(H_{\rho}, H_{\varphi}\right.$ and $\left.E_{z}\right)$ are required, such that Poynting vector's axial component could be different from zero, $P_{\mathrm{z}}=E_{\rho} H_{\varphi}-E_{\varphi} H_{\rho} \neq 0$.

The effectiveness of axial output is greatly dependent on the amount of field matching at the interaction space / output waveguide interface. The task may (and does) prove difficult because of differences in the topology and size of the interaction space (doubly connected coaxial structure) and the output line (singly connected, oversized waveguide and/or horn). In principle, the task might be solvable either in terms of a'purely diffractional' method of extraction, or by means of providing additional structural elements to form directional radiation of microwaves into the guide and further on. The diffractional technique shall envisage coherent radiation of microwaves by properly phase-matched hf currents that flow in parts of the entire output aperture. In this paper we will not dwell on practical ways for implementing diffractional output, rather leaving these for a later publication.

In the alternative case certain vanes of the SWS are electrically connected to the additional structural elements placed outside the anode-cathode block, some distance into the output waveguide. The mechanical size of such elements makes fractions of the wavelength to be radiated, so that these elements could serve as antennas directing and radiating the microwave field into the waveguide and toward the end of the device. Apparently, the distinction between the two approaches is rather thin, since the additional structural elements placed in the guide are connected to the SWS in a similar periodical manner as phase matching is done for the 'pure' diffractional output. Specific details concerning methods of power extraction from a RMAO device are listed in Table 1.

Shown in Fig. 2 are typical configurations of the elements employed for exciting the oversized output waveguide. More details are presented on the 48-cavity magnetron, RM-48, and implementation of the 'antenna-based' method of field radiation into the output guide. The elemental antennas used in experimental work and in simulations were metal rods of different lengths (usually, proportional to $\lambda / 4$ where $\lambda$ is the freespace wavelength), and a single circular wire ring.

Table 1

Techniques of extracting microwaves from a RMAO, analyzed through numerical simulation

\begin{tabular}{|c|c|c|}
\hline Field forming method & Diffractional & Antenna-based \\
\hline \multirow{5}{*}{ Kind of elements } & $\begin{array}{c}\text { Set of } N \text { open resonant cavities } \\
\text { in the RM, } \\
\mathrm{N}=30,40,48\end{array}$ & $\begin{array}{c}\text { Short metal rods }(l=n \lambda / 4) \text {, differing in number } \\
\text { and way of connection to SWS vanes } \\
\text { (uniformly in azimuth or in discrete groups) }\end{array}$ \\
\cline { 2 - 3 } & $\begin{array}{c}\text { Oversized horn with its greater diameter } \\
\text { close to SWS outer diameter }\end{array}$ & $\begin{array}{c}\text { Wire rings }(l=n \lambda / 2) \text { with a variety of connec- } \\
\text { tion points to } S W S \text { vanes } \\
\text { (either uniformly or in groups) }\end{array}$ \\
\cline { 2 - 3 } & Grooves, corrugations, diaphragms & $\begin{array}{c}\text { A single, large sized circular ring }\left(d \approx d_{\text {EDS }}\right) \\
\text { with aperture face normal to guide's axis, } \\
\text { fed from one or a few non-adjacent vanes }\end{array}$ \\
\hline
\end{tabular}



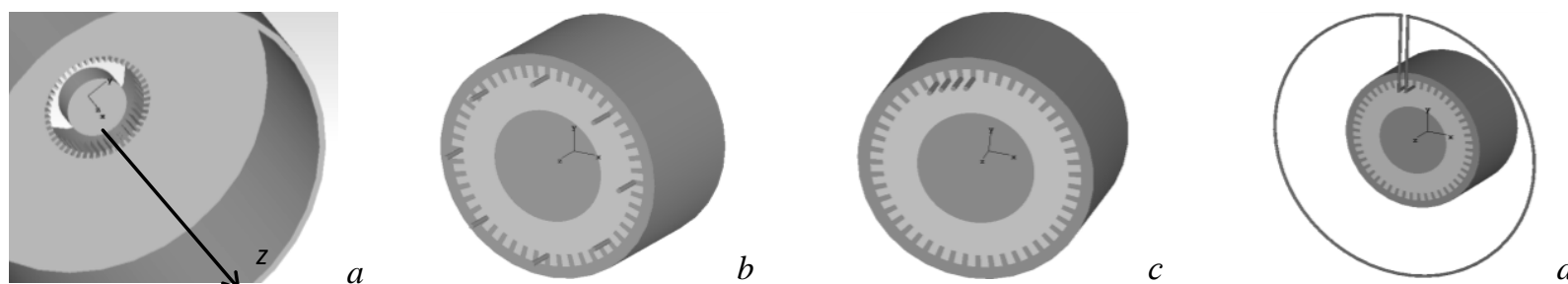

Fig. 2. Configurations of exciter elements for the oversized waveguide: EDS and waveguide, general view (a); $E D S$ with eight rods of lengths $\approx \lambda / 2$, located uniformly about periphery $(b) ;$ EDS with a group of four rods, lengths $\approx \lambda / 2(c)$, EDS with a circular ring antenna, connected to neighboring vanes $(d)$

\begin{tabular}{|c|c|c|c|c|c|c|}
\hline $\begin{array}{c}\text { EDS } \\
+ \text { structure }\end{array}$ & $\begin{array}{l}U_{\mathrm{C}-\mathrm{A}} \\
(\mathrm{V})\end{array}$ & $\begin{array}{l}\text { Electron flow } \\
\text { in SWS }\end{array}$ & $\begin{array}{l}\text { E-field distribu- } \\
\text { tion within } \\
\text { waveguide's } \\
\text { cross-section }\end{array}$ & $\begin{array}{l}\text { Oscillation spec- } \\
\text { trum within EDS }\end{array}$ & $\begin{array}{c}\text { Spectrum near } \\
\text { waveguide's end }\end{array}$ & $\begin{array}{l}\text { Power } \\
\text { (MW) }\end{array}$ \\
\hline $\begin{array}{l}\text { EDS+ wave- } \\
\text { guide, no } \\
\text { antennas }\end{array}$ & 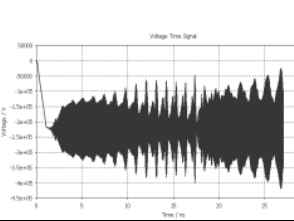 & $\sim \pi / 2$ & -2) & $\mid$\begin{tabular}{c|c|c|}
$\mid$ & \\
& & \\
0
\end{tabular} & 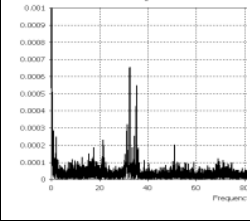 & 0.5 \\
\hline $\begin{array}{l}\text { EDS+twelve } \\
\text { rods, } l \approx 0.5 \lambda\end{array}$ & & $\sim \pi / 2$ & & 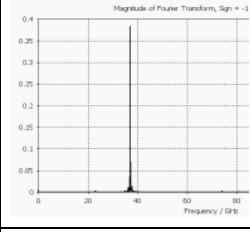 & 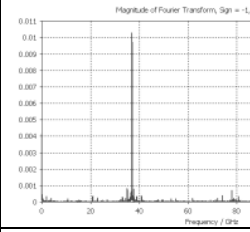 & 11.0 \\
\hline $\begin{array}{l}\text { EDS+five } \\
\text { rods, } l \approx 0.5 \lambda\end{array}$ & 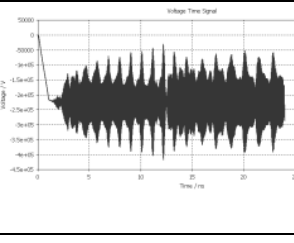 & $\sim \pi / 2$ & & 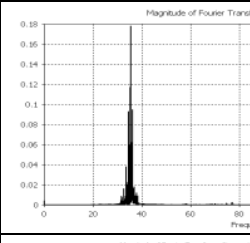 & 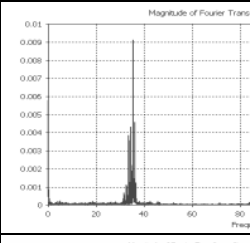 & 5.2 \\
\hline $\begin{array}{c}\text { EDS with } 12 \\
\text { groups of } 3 \\
\text { rods: } l=0.25 \lambda \\
0.5 \lambda, 0.75 \lambda\end{array}$ & $\ldots$ & $\sim \pi / 2$ & & $\lim _{n}^{+\infty}$ & 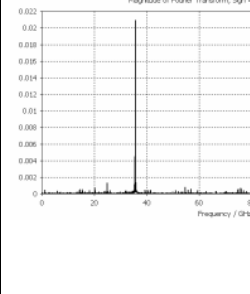 & 19.5 \\
\hline $\begin{array}{l}\text { EDS+circular } \\
\text { ring } \\
\text { dia }=54.1 \mathrm{~mm} \\
\end{array}$ & & & & 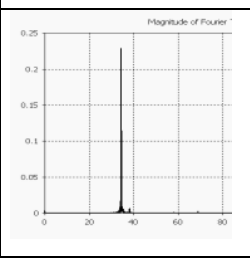 & 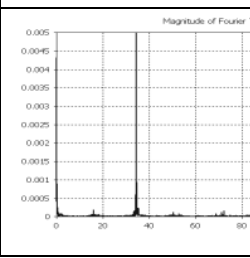 & 11.7 \\
\hline
\end{tabular}

Fig. 3. Characteristics of microwave radiation from RMAOs, as obtained in numerical experiments for several power extracting elements (anode voltage $U_{0}=220 \mathrm{kV}$, magnetic field $H_{0}=5.7 \mathrm{kOe}$, e-beam current $I=0.7 \mathrm{kA}$ )

The results of numerical experiments were evaluated taking into account, before all, the depth of high frequency 'modulation' of the pulsed driving waveform (data from a voltage monitor in the anode-cathode gap), process of spoke formation in the SWS, intensity and spectral width of the output signal and amount of microwave power at the exit from the oversized waveguide (Fig. 3).

As can be seen, with equal magnitudes of $U_{0}$ and $H_{0}$, as well as of emission current from the cathode, the conditions for effectively exciting the magnetron's EDS and outputting the radiation depended rather strongly upon the type and mutual arrangement of the 'antenna' elements. A series of numerical experiments with dif- ferent rod antennas has demonstrated that better results with regard to driving the RM and outputting the radiation were obtained for 8 or 12 rods (about $\lambda / 2$ in length) that were placed on end faces of the EDS cavities, at regular intervals in azimuth (covering widths of either one or several adjacent cavities). Rather good results were demonstrated when three to five rods were united in one group but electrically connected to neighboring lamellas of the SWS. The length of the rods was varied in steps of $0.25 \lambda$, from 0.25 to $0.75 \lambda$.

A rather uniform radiated field distribution at the end face of the oversized waveguide, and a high output power at that, were produced by wire ring antennas whose aperture plane was perpendicular to the guide's 
axis. (Their diameters were commensurate with such of the SWS). Depending on the operation mode of the RM $(\pi / 2$ or $\pi)$ such loops could be connected to walls of either one and the same or several non-adjacent cavities of the SWS. Shown in Fig. 4 are output radiation intensities dependent on geometrical parameters of such a loop. Calculated parameters of the antennas mentioned are listed in Table 2. The Table also contains calculated parameters of a RMAO involving no antenna-like elements. That plays the part of a basic RMAO configuration.
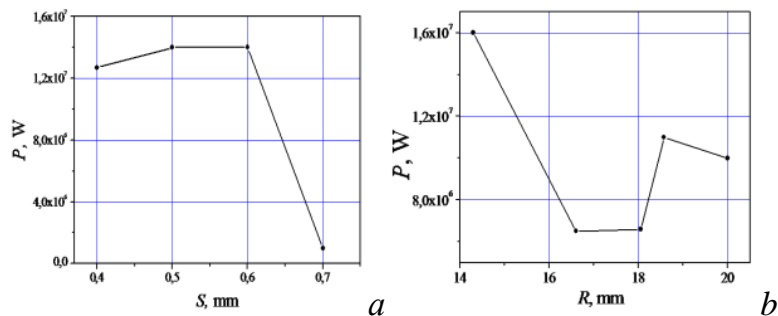

Fig. 4. The dependences of RMAO output power on loop separation from the end cross-section of the EDS (a) and upon the loop's radius (b)

A sizable amount of numerical work has been done for the conditions corresponding to the "purely diffractional' mode of radiation. Supposedly, the results will be presented in a series of further publications.

\section{EXPERIMENTS WITH RMAOs}

The electrodynamic structure of the experimental RM discussed in the present paper involved 48 sectoral cavities of inner diameter $22 \mathrm{~mm}$ and length $6 \mathrm{~mm}$. The SWS period was $1.44 \mathrm{~mm}$, while the cavity width at the inner diameter level) was $0.84 \mathrm{~mm}$ and depth $1.49 \mathrm{~mm}$. The SWS is co-axial with the magnetron as a whole, sitting at the interface with the circular oversized waveguide $\left(d_{\mathrm{wg}}=80 \mathrm{~mm}\right)$. A cathode of diameter $d_{\mathrm{C}}=14 \mathrm{~mm}$ is at the center (see Fig. 1). A special structural feature of the EDS, compared with previous embodiments, is the presence of antenna elements connected to certain cavities of the SWS, Fig. 5. Microwave radiation from the RMAO-48 was investigated experimentally for EDS versions involving different combinations of antenna rods. Like in the numerical experiments, the rod lengths were varied in steps of $\lambda / 4$ (see the general view of the SWS in Fig. 5,a).
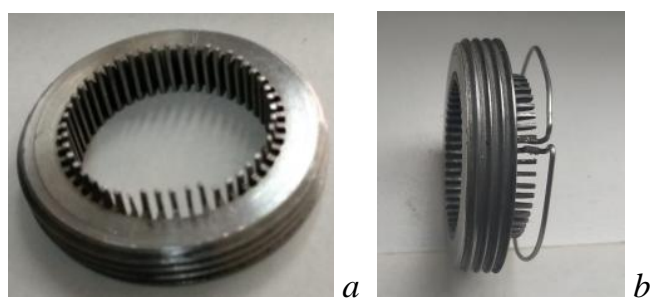

Fig. 5. The EDS of RM-48 with different output elements ('antennas'): rods (a) and a wire ring (b)
Along with that, an electrodynamic structure was analyzed that contained 42 'antenna' rods $l=\lambda / 2$ connected to correspondent 42 SWS cavities, plus an additional wire ring element connected to two adjacent rods (Fig. 5,b). The separation between the EDS' end face and the plane of the ring equaled $5 \mathrm{~mm}$. So, the total length of the microwave current circuit (including the circle length and that of connecting wires was close to $12 \lambda$ or $13 \lambda$.).

The measurements concerned spectral content and output power of the radiated microwaves. Measurements of the generated frequency proceeded from two techniques, specifically a coarse and a more precise method. The initial evaluation of the frequency range where generation could occur was done through spotting the generation band with a lower frequency bandpass filter. Precise measurements were performed in a heterodyne technique, using a $\Gamma 4-115$ signal generator as the heterodyne and the standard mixer of the C4-60 spectrum analyzer. The IF frequency was measured directly with a digital oscilloscope (Agilent DSO80404B, $4 \mathrm{GHz}$ bandwidth)

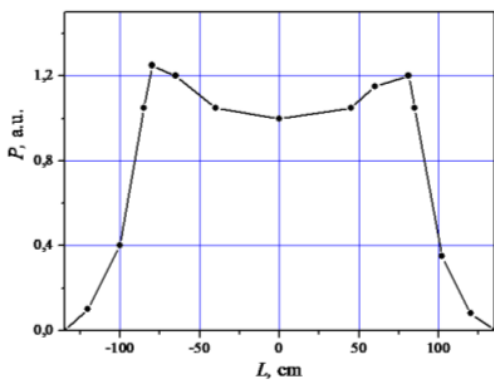

Fig. 6. Horizontal-plane radiation pattern of RMAO

The pulsed radiated power was estimated from readings of a registration module $P_{\text {REC }}$ placed at $1.5 \mathrm{~m}$ off the output waveguide. The module involved a horn antenna, a set of attenuators 0 to $-70 \mathrm{~dB}$, and a detector head. It had been pre-calibrated with the use of a $\Gamma 4-115$ signal generator and a M3-22a power meter. The procedure of evaluating the extracted microwave power made use of the radiation pattern of the circular output waveguide that was measured within the horizontal and the vertical plane, see Fig. 6. The measurements showed roughly equal power distributions for the two planes, suggesting a nearly spherical radiation pattern (with a slight depression about the central zone). The radiated power was calculated from

$$
P_{\mathrm{MW}}=2 \pi R^{2} K_{\mathrm{ATT}} P_{\mathrm{REC}} / \mathrm{S}_{\mathrm{EFF}} K_{\mathrm{a}},
$$

where $R$ is the distance from the output waveguide to the receiving antenna; $K_{\mathrm{ATT}}$ the total attenuation in the attenuators; $P_{\mathrm{REC}}$ the power level as read from the calibrated detector; $\mathrm{S}_{\mathrm{EFF}}=7 \mathrm{~cm}^{2}$ effective area of the receive antenna, and $K_{\mathrm{a}}=3.7$ the output waveguide's gain factor as estimated from measured data on the antenna pattern. Measurement results concerning output microwave power and generated frequencies are presented in Table 2.

Table 2

Measured levels of output power demonstrated by RMAOs with different output structures $\left(U_{0}=200 \ldots 220 \mathrm{kV} ; H_{0}=5\right.$ to $6 \mathrm{kOe} ; I \approx 2 \mathrm{kA}$, and $f_{M W}=34.5$ to $\left.35.4 \mathrm{GHz}\right)$

\begin{tabular}{|c|c|c|c|c|c|}
\hline $\begin{array}{c}\text { Type of 'antenna' } \\
\text { element }\end{array}$ & None & $\begin{array}{c}48 \text { rods } \\
(3 \text { pieces of length } \\
l=0.75 \lambda ; 45 \mathrm{pcs} \text { of } l=0.5 \lambda)\end{array}$ & $\begin{array}{c}48 \text { rods } \\
(4 \mathrm{pcs} \text { of } l=0.75 \lambda ; \\
44 \mathrm{pcs} \text { of } l=0.5 \lambda)\end{array}$ & $\begin{array}{c}48 \text { rods } \\
(5 \mathrm{pcs} \text { of } l=0.75 \lambda ; \\
43 \mathrm{pcs} \text { of } l=0.5 \lambda)\end{array}$ & $\begin{array}{c}42 \text { rods of } l=0.5 \lambda \\
\text { and a wire ring, } \\
\text { dia. } d=30.8 \mathrm{~mm}\end{array}$ \\
\hline Output power, MW & 0.05 & 4.2 & 9.0 & 30.0 & 20.0 \\
\hline
\end{tabular}




\section{CONCLUSIONS}

The axial mode of microwave power extraction from a millimeter wave relativistic magnetron has been studied experimentally and via numerical simulation. The oversized output waveguide of single-connected topology involved special-purpose antennas in the form of resonant rods or wire loops, elect-rically connected to certain points at the SWS cavity surfaces. The efficiency of microwave extraction has proven to be strongly dependent on the size and structure of those antenna elements. Compared with RMAO EDS versions containing no antennas, the efficiency can be increased by a factor of $10^{1}$ to $10^{2}$.

\section{REFERENCES}

1. I.I. Magda, N.P. Gadetski, E.I. Kravtsova, et al. Relativistic Magnetron of $8 \mathrm{~mm}$ Waveband // Problems of Atomic Science and Technology. Series "Plasma Electronics and New Methods of Acceleration". 2008, № 4, p. 18-20.

2. I.I. Magda, S.A. Berdin, N.P. Gadetski, et al. A millimeter-wavelength relativistic magnetron // XVIII-th Int'l Conference "VHF devices and telecommunication technologies". 2008, Sevastopol, Crimea, Ukraine, p. 637-639.

3. J. Benford, J.A. Swegle. High power microwaves. Artech House, Inc., Boston, London. 1992, p. 149.

4. V.E. Nechayev et al. The Relativistic Magnetron // High-frequency relativistic electronics / Publi-shed by the Institute for Applied Physics, Acad. Sci. USSR, Gorky. 1979, p. 114-129.

5. M.I. Fuks, E. Schamiloglu. $70 \%$ efficient relativistic magnetron with axial extraction of radiation through a horn antenna // IEEE Trans Plasma Sci. 2010, v. 38, № 6, p. 1302-1312.

6. S.A. Berdin, K.V. Chizhov, N.P. Gadetski, V.G. Korenev, A.N. Lebedenko, M.I. Marchenko, I.I. Magda, O.G. Melezhik, V.G. Sinitsin, and V.A. Soshenko. Special traits of the millimeter wave relativistic magnetron // Problems of Atomic Science and Technology. Series "Nuclear Physical Investigations”. 2014, № 3, p. 54-59.

7. N.P Gadetsky, A.N. Lebedenko, I.I. Magda, O.G. Melezhik, A.A. Shtanko, V.G. Sinitsin, and M.V. Volovenko. A relativistic magnetron-type source of nanosecond-length pulsed radiation in the $8 \mathrm{~mm}$ waveband // Problems of Atomic Science and Technology. Series "Nuclear Physics Investigations”. 2017, № 36, p. 42-44.

8. S.A. Berdin, N.P. Gadetski, V.G. Korenev, I.I. Magda, O.G. Melezhik, V.A. Soshenko, K.V. Chizhov, and A.I. Shevbtsova. Current distributions in a $8-\mathrm{mm}$ wavelength relativistic magnetron // XXI-st Int'l Conference "VHF devices and telecommunication technologies”. 2011, Sevastopol, Crimea, Ukraine, p. 833-835.

Article received 12.10 .2021

\section{РЕЛЯТИВИСТСКИЙ МАГНЕТРОН МИЛЛИМЕТРОВОГО ДИАПАЗОНА: ПРОБЛЕМА ВЫВОДА МИКРОВОЛНОВОЙ ЭНЕРГИИ}

\section{Н.П. Гадецкий, В.Г. Коренев, А.Н. Лебеденко, И.И. Магда, О.Г. Мележик, В.Г. Синицын, А.А. Штанько, Н.В. Воловенко}

В миллиметровом диапазоне длин волн исследователи релятивистских магнетронов сталкиваются с проблемой низкой эффективности вывода микроволновой энергии из цилиндрической структуры - как в радиальном направлении, так и в аксиальном. Аксиальный вывод, которому отдается предпочтение, технически может быть реализован либо за счет дифракционных эффектов, либо путем введения в структуру выходного волновода дополнительных резонансных элементов. Обсуждаются несколько методов аксиального вывода, в том числе путем размещения петлевых антенн в концевой плоскости анод-катодного блока или штырей резонансной длины вблизи резонаторов замедляющей системы. Такими методами удалось повысить эффективность вывода энергии в рассмотренных системах в $10^{1} \ldots 10^{2}$ раз.

\section{РЕЛЯТИВІСТСЬКИЙ МАГНЕТРОН МІЛІМЕТРОВОГО ДІАПАЗОНУ: ПИТАННЯ ВИВЕДЕННЯ МІКРОХВИЛЬОВОЇ ЕНЕРГІЇ}

\section{М.П. Гадецький, В.Г. Коренєв, О.М. Лебеденко, І.І. Магда, О.Г. Мележик, В.Г. Сініцин, А.О. Штанько, М.В. Воловенко}

У міліметровому діапазоні довжин хвиль дослідники релятивістських магнетронів стикаються 3 проблемами щодо ефективності виведення мікрохвильової енергії - як у радіальному напрямку циліндричної структури, так і в аксіальному. Аксіальний спосіб, котрому надається перевага, може бути реалізованим або в суто дифракційних техніках, або шляхом введення в структуру вихідного хвилеводу додаткових резонансних елементів. Обговорюються декілька методів аксіального виведення, включаючи розміщення петлевих антен на кінцевій площині анод-катодного блоку або штирів резонансної довжини біля резонаторів структури уповільнення. Такі заходи дозволили підвищити ефективність виведення мікрохвиль у системах, що розглянуто, у $10^{1} \ldots 10^{2}$ разів. 